\title{
TINJAUAN YURIDIS NORMATIF TERHADAP FENOMENA PENOLAKAN ORGANISASI KEMASYARAKATAN (ORMAS) TERHADAP PENERAPAN UNDANG-UNDANG NO 16 TAHUN 2017 TENTANG ORGANISASI KEMASYARAKATAN
}

\author{
Muhamad Rezky Pahlawan MP \\ Fakultas Hukum, Universitas Pamulang \\ dosen02082@unpam.ac.id
}

\begin{abstract}
Community organizations are a forum for every citizen to be able to achieve political rights in a democratic country like Indonesia. The continuation of political dynamics has made community organizations an important element in the development of democratic maturity in Indonesia. It must be realized that all aspects of the sustainability of community organizations have an important subject where the legal basis underlying the existence of a community organization is the main thing. The new law on Community Organizations has a real polemic that raises pros and cons, so research is based on a theoretical review of Law No. 16 of 2017 concerning Community Organizations using the method of using qualitative research methods with descriptive analysis method, namely analyzing data on objects and research subjects within the scope of Law No. 16 of 2017 concerning Community Organizations. In fact, the new Law on Civil Society Organizations is inserted points relating to the prohibition of CSOs to raise funds for political parties and to take an active role in practical politics. for the existence of mass organizations in Indonesia.
\end{abstract}

Keywords: community organization, democracy, society participation

\begin{abstract}
ABSTRAK
Organisasi masyarakat merupaka suatu wadah bagi setiap warga Negara untuk dapat meraih hak politik di Negara demokrasi seperti Indonesia ini. Keberlangsungan dinamika politik menjadikan organisasi masyarakat menjadi salah satu element penting dalam perkembangan kedewasaan demokrasi di Indonesia. Perlu disadari bahwa segala aspek keberlangsungan organisasi masyarakat memiliki subjek yang penting dimana dasar hukum yang melandasi adanya suatu keberadaan organisasi masyarakat menjadi hal yang utama. Undang-undang yang baru tentang Organisasi Masyarakat memiliki polemik nyata yang menimbul pro dan kontra, sehingga penelitian berlandaskan tinjauan teoritis terhadap Undang-undang No. 16 Tahun 2017 tentang Organisasi Masyakarat dengan metode Menggunkan jensi penelitian kualitatif dengan metodedeskriptif analisis yaitu menganalisa data pada objek dan subjek penelitian dalam lingkup Undang-undang No 16 Tahun 2017 tentang Organisasi Kemasyarakatan. Bahkan dalam Undang-undang tentang Ormas yang baru tersebut disisipkan point berkaitan dengan larangan ormas untuk mengumpulkan dana untuk partai politik dan turut aktif dalam politik praktis Kekhawatiran terhadap peran dan posisi ormas sebagaimana dipaparkan di atas mendorong lahirnya Undang-Undang Ormas yang baru sebagai regulasi yang kuat bagi keberadaan ormas di Indonesia.
\end{abstract}

Kata kunci: Organisasi Masyarakat, Demokrasi, Partisipasi Masyakarat 


\section{PENDAHULUAN}

Ormas lahir sebaga salah satu wujud dari partisipasi masyarakat dalam mengembangkan demokrasi dalam upaya menjunjung tinggi kebebasan, kesetaraan, kebersamaan, dan kejujuran. Ormas merupakan organisasi yang dibentuk oleh sekelompok warga negara Republik Indonesia secara sukarela atas dasar persamaan kehendak dan cita-cita untuk memperjuangkan kepentingan anggota, masyarakat, bangsa, dan negara. Organisasi kemasyarakatan (Ormas) di Indonesia banyak mengalami posisinya pasang-surut, terutama semejak kasuskasus yang marak terjadi baru-baru ini seperti ormas yang melakukan aktifitas yang melampaui batasnya dalam bentuk razia barang-barang tertentu, persekusi jalanan atau melakukan aksi memburu orang-orang yang mereka anggap mencemarkan nama salah satu tokoh internal ormas tersebut hingga pada kasus ormas yang melakukan politik praktis bahwa ormas terlibat sebagai mesin partai politik. Sehingga atas dasar tersebutlah pemerintah menganggap bahwa UU No 17 Tahun 2013 Tentang Organisasi Kemasyarakatan sudah tidak dapat lagi menekan aksi organisasi masa (ormas) yang melampaui tugas dan kewenangannya hingga akhirnya munculah PERPU Nomor 2 Tahun 2017 Tentang Organisasi Kemasyarakatan, dengan pertimbangan Bahwa konteks keberadaan Organisasi Kemasyarakatan telah mendesak untuk segera dilakukan perubahan karena belum mengatur secara komprehensif mengenai keormasan yang bertentangan dengan Pancasila dan Undang-Undang Dasar Negara Republik Indonesia Tahun 1945 sehingga terjadi kekosongan hukum dalam hal penerapan sanksi yang efektif, dan organisasi kemasyarakatan tertentu yang dalam kegiatannya tidak sejalan dengan asas organisasi kemasyarakatan sesuai dengan anggaran dasar organisasi kemasyarakatan yang telah terdaftar dan telah disahkan Pemerintah, dan bahkan secara faktual terbukti ada asas organisasi kemasyarakatan dan kegiatannya yang bertentangan dengan Pancasila dan Undang-Undang Dasar Negara Republik Indonesia Tahun 1945 serta Organisasi Kemasyarakatan belum menganut asas cantrarius actus sehingga tidak efektif untuk menerapkan sanksi terhadap organisasi kemasyarakatan yang menganut, mengembangkan, serta menyebarkan aliaran atau paham yang bertentangan dengan Pancasila dan Undang-Undang Dasar Negara Republik Indonesia Tahun 1945 .

Aksi-aksi kekerasan yang dilakukan ormas sering terjadi dan dikhawatirkan akan memecah belah persatuan yang telah terjalin di Indonesia. Sementara itu kompleksitas tantangan yang dihadapi aparat penegak hukum dalam mengawasi keberadaan ormas-ormas menghadapi kesulitan untuk mengawasi dan melakukan pembinaan,terlebih masih banyak ormas yang belum terdaftar resmi di Kemendagri, sehingga aparat penegak hukum kesulitan untuk memberikan sanksi terhadap ormas ormas yang melanggar ketentraman dan keamanan dengan hanya mengandalkan UU No. 17 Tahun 2013. Oleh karena itu, sejalan dengan telah dikeluarkannya PERPU yang kini telah disahkan menjadi Undang-undang No. 02 Tahun 2017 tentang Organisasi Kemasyarakatan maka diperlukan adanya kajian mendalam mengenai lingkup pertanggungjaawban hukum Ormas sebagai bentuk implementasi pasal 59 ayat (1), (2), (3) dan (4) dalam Undang-undang No. 02 Tahun 2017 tentang Organisasi Kemasyarakatan.

Bahwa dalam Undang-undang tentang Ormas yang baru tersebut disisipkan point berkaitan dengan larangan ormas untuk mengumpulkan dana untuk partai politik dan turut aktif dalam politik praktis Kekhawatiran terhadap peran dan posisi ormas sebagaimana dipaparkan di atas mendorong lahirnya Undang-Undang 
Ormas yang baru sebagai regulasi yang kuat bagi keberadaan ormas di Indonesia. Sehingga pelarangan atau kesewenangan dalam pengekangan tidak dapat dibenarkan Pasal 1 ayat (3) UUD 45, menyatakan bahwa Negara Indonesia adalah negara hukum, bukan negara kekuasaan belaka. Suatu negara hukum, seperti diungkapkan oleh Frans Magnis Suseno, adalah didasarkan pada suatu keinginan bahwa kekuasaan negara harus dijalankan atas dasar hukum yang baik dan adil. Hukum menjadi landasan dari segenap tindakan negara, dan hukum itu sendiri harus baik dan adil. Baik karena sesuai dengan apa yang diharapkan oleh masyarakat dari hukum, dan adil karena maksud dasar segenap hukum adalah keadilan. Ada empat alasan utama untuk menuntut agar negara diselenggarakan dan menjalankan tugasnya berdasarkan hukum, yaitu: (1) kepastian hukum, (2) tuntutan perlakuan yang sama (3) legitimasi demokratis, dan (4) tuntutan akal budi (Frans Magnis, 1988:295).

Indonesia merupakan Negara hukum dimana dalam arti formal the rule of law berarti organized public power, atau kekuasaan umum yang terorgainsasi. Dalam arti material, the rule of law didefinisikan sebagai rule of just law, artinya dalam konsep the rule of law, di dalamnya tercakup pula keadilan yang sifatnya lebih substantive dan esensial, tidak sekadar memfungsikan bunyi dari undang-undang tertulis. Tentang persamaan di depan hukum, A.V Dicey menerangkan semua kelompok masyarakat memiliki ketertundukan yang sama di mata hukum umum Negara, yang di jalankan oleh peradilan umum. The Rule of Law tidak mengenal adanya pengecualian bagi pejabat pemerintah atau orang-orang tertentu terhadap hukum yang mengatur warganegara secara keseluruhan, seperti halnya ada pengadilan administrative (A.V. Dicey, 2008:262).

Transparansi

dan pertanggungjawaban publik juga menjadi nilai buruk bagi sebagian besar ormas di Indonesia. Tak hanya itu, beberapa ormas sangat bergantung pada pemerintah ataupun pihak lain (dalam maupun luar negeri) untuk mendukung seluruh kegiatannya. Bahkan dalam Undangundang tentang Ormas yang baru tersebut disisipkan point berkaitan dengan larangan ormas untuk mengumpulkan dana untuk partai politik dan turut aktif dalam politik praktis Kekhawatiran terhadap peran dan posisi ormas sebagaimana dipaparkan di atas mendorong lahirnya Undang-Undang Ormas yang baru sebagai regulasi yang kuat bagi keberadaan ormas di Indonesia.

\section{METODE PENELITIAN}

Penelitian ini menggunakan metode penelitian Menggunkan jensi penelitian kualitatif dengan metodedeskriptif analisis yaitu menganalisa data pada objek dan subjek penelitian dalam lingkup Undangundang No 16 Tahun 2017 tentang Organisasi Kemasyarakatan. Pada penelitian ini menggunakan pendekatan yuridis normatif, yaitu penelitian hukum secara yuridis yakni penelitian yang mengacu pada studi kepustakaan pengumpulan data yang berkaitan dengan menelaah literatur, kajian teori para ahli hukum berupa buku-buku ilmiah, Undangundang, yang berkaitan dengan organisasi kemasyarakatan, artikel yang sumbernya dapat di pertanggungjawabkan serta tulisan yang ada kaitanya dengan judul yang dbahas. Data yang diperoleh dan digunakan sebagai penunjang dan elengkap dalam penyusunan penelitian ini. Sedangkan bersifat normatif dilakukan untuk hubungan antara satu peraturan dengan eraturan lainya dan penerapan dalam perakteknya serta kajian teoritis dalam memecahkan permasalahan yang akan dibahas dalam penelitian ini. 


\section{PERMASALAHAN}

Adapun agar memberikan arahan terhadap penulisan ini, maka penulis membatasi ruang lingkup permasalahan pada bagaimana kedudukan Organisasi Masyarakat pasca perubahan Undangundang Organsiasi Maysarakat setelah direvisi?

\section{PEMBAHASAN}

Keberadaan Organisasi di tengah Masyarakat berkaitan dengan Undangundang No 16 Tahun 2017.

Organisasi adalah alat untuk mencapai ideologi dengan politik atau cara tertentu. Untuk mencapai tujuan (ideologi) dan melalui cara (politik) tertentu tidak mungkin dilakukan secara sendiri-sendiri tanpa kepemimpinan, anggota atau tanpa dukungan massa rakyat yang luas. Konsep masyarakat yang dikemukakan oleh Arbi Sanit itu searah dengan pemikiran daripada Von Savigny sebagaimana dikutip oleh (Antonius Cahyadi, 2007:133) bahwa:

"Rakyat sebagai sebuah kesatuan individu yang beraneka ragam (kepentingan, kebutuhan, cita-cita, dan lainlainnya)aa hidup dalam keteraturan"

Konsep rakyat (volk atau people) menjadi konsep sentral bagi seluruh pemikiran Savigny (terutama tentang hukum). Romantismenya bersumber dari rakyat dinamika kerakyatan yang terwujud dalam kebudayaan dan keseniannya. Istilah rakyat mengacu pada entitas kebangsaan. Dalam hal ini konsep rakyat dilihat sebagai kesatuan semangat, terdapat bukan sekedar kumpulan individu-individu karena individu-individu secara satu-persatu tidak memiliki makna sama sekali dihadapkan pada istilah rakyat. Prinsip garis massa adalah prinsip yang mengatur agar organisasi tidak jatuh pada komandoisme atau kecenderungan untuk bergerak jauh meninggalkan kesadaran politik obyektif massa dan situasi politik sehingga organisasi hanya bergerak berdasarkan pikiran-pikiran subyektifnya saja yang jauh diatas keberanian massa rakyat. Massa rakyat adalah tulang punggung dalam perjuangan demokrasi, massa rakyatlah yang akan bergerak untuk merebut kekuasaan dan masa depannya untuk kepentingan massa rakyat juga. Garis massa hanya akan bisa dimiliki oleh organisasi progresif yang selalu berada dalam perjuangan bersama dengan massa rakyat. Garis massa pun mempertegas arti bahwa perjuangan ini semua adalah untuk kepentingan massa rakyat. Dalam pelaksanaannya setiap anggota harus hidup ditengah massa rakyat, mendengar pandangan-pandangan rakyat dan kemudian menyimpulkan serta melaporkan pada organ yang diatasnya. Organ yang lebih atas kemudian mempelajari dan memutuskan langkah dan gerak yang harus diambil oleh anggota pada massa rakyat dimana dia tinggal dan berjuang bersama. Massa rakyat adalah tulang punggung dalam perjuangan demokrasi, massa rakyatlah yang akan bergerak untuk merebut kekuasaan dan masa depannya untuk kepentingan massa rakyat juga. Dalam perkembangan masyarakat ke arah demokratisasi, gejala kegiatan berorganisasi juga tumbuh rasional mengikuti tuntutan alamiah setiap orang dalam bermasyarakat. Jika tuntutan bermasyarakat adalah kecenderungan alamiah setiap individu manusia sebagai makhluk sosial, maka kecenderungan untuk berkelompok dan berorganisasi juga merupakan kecenderungan alamiah yang terdapat dalam setiap masyarakat manusia itu (Jimly Asshiddiqie, 2006:43-44). Kedua jenis organisasi memiliki persamaan untuk menerima peranan ideologi di dalam kehidupannya. Perbedaannya adalah pada organisasi gerakan masyarakat, ideologi 
dianggap sebagai gambaran umum dari apa yang sebaiknya dicapai oleh organisasi dan sudah menjadi tugas organisasi untuk merumuskan tujuan yang jelas dan bersifat operasional tersebut. Namun, dalam organisasi kemasyarakatan ideologi memegang peranan penting dalam mempertajam formulasi tujuan organisasi, merekatkan semua anggota yang berjumlah besar, memberikan identitas kepada semua anggota dan ideologi digunakan untuk menuntut organisasi dalam memainkan peranannya terhadap kehidupan politik di Indonesia.

Para pengkritik Perpu ini mengabaikan bahwa demokrasi juga memerlukan pembatasan atas kebebasan, karena tanpa itu akan menjadi anarki. Pembatasan kebebasan itu justru untuk melindungi dari sisi gelap demokrasi dimana kebebasan yang berlebihan tanpa pengaturan efektif akan menimbulkan konflik dan anarki akibat hancurnya otoritas negara untuk melindungi kepentingan masyarakat. Hal yang juga ironi, argumentasi tentang demokrasi, HAM dan kebebasan juga dinyatakan oleh HTI untuk mengcounter Perpu Ormas, sementara HTI selama ini mengharamkan demokrasi. Sikap ini menunjukan watak hipokrit dari HTI dan membuka mata publik tentang HTI sebenarnya. Kesimpulan bahwa Perpu merupakan produk otoritarianisme negara juga sangat tidak beralasan.Negara otoriter biasanya dicirikan dengan machstaat atau negara berdasarkan kekuasaan belaka.Perpu Ormas ini justru memberi ruang pada publik yang merasa dirugikan untuk membela diri dalam sengketa tata usaha negara di PTUN untuk menguji kewenangan Mendagri/Menkumham dalam pencabutan/pembubaran Ormas. Begitupula dengan peradilan Pidana untuk membela diri atas dugaan pidana pelanggaran Perpu Ormas.Mekanisme hukum yang tersedia ini merupakan ciri negara berdasar hukum atau rechstaat yang membedakannya dengan negara otoriter.

Juru bicara Mahkamah Konstitusi (MK) Fajar Laksono mengatakan, sidang uji materi Peraturan Pemerintah Pengganti Undang-Undang Nomor 2 Tahun 2017 yang telah disahkan menjadi Undang-undang No 16 Tahun 2017 tentang Organisasi Kemasyarakatan ( Perppu Ormas) tidak bisa dilanjutkan kembali sebab peraturan tersebut telah disahkan menjadi undangundang melalui rapat paripurna di DPR. setelah disahkan, maka permohonan gugatan uji materi Perppu Ormas tak lagi memiliki objek gugatan. Organisasi kemasyarakatan merupakan perwujudan dari hak yang dijamin dalam UndangUndang Dasar Negara Republik Indonesia Tahun 1945. Warga negara memiliki kebebasan untuk berserikat, berkumpul, dan mengeluarkan pendapat. Kebebasan untuk berserikat dan berkumpul serta mengeluarkan pendapat tersebut dikenal sebagai tiga kebebasan dasar yang merupakan bagian dari konsep hak-hak asasi manusia, terutama dalam rumpun hak sipil dan politik.

Organisasi kemasyarakatan menjadi sarana untuk menyalurkan pendapat dan pikiran bagi anggota masyarakat Warganegara Republik Indonesia dan dinilai memiliki peranan yang sangat penting dalam meningkatkan keikutsertaan secara aktif seluruh lapisan masyarakat dalam mewujudkan masyarakat Pancasila berdasarkan Undang-Undang Dasar 1945 dalam rangka menjamin pemantapan persatuan dan kesatuan bangsa, menjamin keberhasilan pembangunan nasional sebagai pengamalan Pancasila, dan sekaligus menjamin tercapainya tujuan nasional. Manusia adalah makhluk sosial yang cenderung untuk hidup bermasyarakat serta mengatur dan giat berorganisasi dalam mencapai suatu tujuan, tetapi karena keterbatasan kemampuan menyebabkan mereka tidak mampu mewujudkan tujuan tanpa adanya kerjasama. Hal tersebut yang 
mendasari manusia untuk hidup dalam berorganisasi (Ruknan, 2000:15).

Pasal 28E ayat (3) UUD 1945 menyatakan, "Setiap orang berhak atas kebebasan berserikat, berkumpul, dan mengeluarkan pendapat". Sebagian dari ormas telah melakukan kegiatan positif dengan menyertakan masyarakat seperti menjaga lingkungan hidup, membantu masyarakat dalam bidang hukum, dan dibidang lainnya dengan melakukan peranan yang aktifitas kemasyarakatannya dilakukan secara damai dengan memperdayakan masyarakat, disisi lain terdapat pula organisasi kemasyarakatan yang melakukan perbuatan kurang terpuji.

Kebebasan berpendapat secara esensi bukan saja memberikan kebebasan mengeluarkan pendapat baik lisan maupun tulisan tetapi jauh dari itu mengandung makna kebebasan untuk berekspresi dengan bertanggungjawab baik secara niat, etika, substansi, hukum, maupun bertanggung jawab dan siap menerima sanksi sosial dan hukum apabila ternyata pendapat yang dikemukakannya dimuka umum dianggap telah melanggar ketentuan perundangundangan. Artinya kebebasan yang terkandung didalamnya tidak boleh mencederai nilai-nilai kesusilaan, ketertiban, dan keutuhan bangsa, juga keagamaan.

Contoh dari peran ini diambil oleh LSM yang bergerak di bidang lingkungan, seperti Wahana Lingkungan Hidup Indonesia (WALHI), yang salah satu kontribusinya yaitu menerima ataupun mengumpulkan keluhan-keluhan dari masyarakat terkait permasalahan lingkungan di sekitar mereka. Keluhankeluhan tersebut kemudian disampaikan kepada institusi terkait, misalnya Badan Pengelola Lingkungan Hidup (BPLH) sebagai instansi pemerintah. Pada proses ini, pemerintah mendapatkan asistensi dari LSM lingkungan dengan menerima informasi tentang keadaan masyarakat yang dirugikan akibat pengelolaan lingkungan yang tidak sesuai. Atas informasi dan aspirasi masyarakat yang didapatkan dari LSM tersebut, dinas pemerintahan yang bersangkutan dapat menindaklanjuti melalui kebijakan atau tindakan. Contoh tersebut memberikan gambaran tentang pola kemitraan LSM dan pemerintah dalam aspek pengelolaan aspirasi masyarakat.

Secara konseptual, pemberdayaan atau empowerment merupakan sebuah proses perubahan, beberapa ahli yang terangkum. Pemberdayaan Organisasi Masyarakat yang baik harus memenuhi kriteria ialah Memenuhi kebutuhan dasarnya sehingga mereka memiliki kebebasan (freedom), dalam arti bukan saja bebas mengemukakan pendapat, melainkan bebas dari kelaparan, kebodohan, dan kesakitan, menjangkau sumber-sumber produktif yang memungkinkan mereka dapat meningkatkan pendapatannya dan memperoleh barang-barang serta jasa-jasa yang mereka perlukan, berpartisipasi dalam proses pembangunan dan keputusankeutusan yang memengaruhi mereka (Suharto, 2005:210).

Dengan sudah terjadi nya perpu ormas yg telah di sahkan menjadi undang undang maka tentu aturan-aturan yang terkandung didalam Undang-undang Organisasi Masyarakat menjadi mengikat dan berlaku terhadap seluruh warga serta memiliki sanksi apabila ada siapapun yang melanggar apa yang ada dalam sebuah ketentuan yang tercantumkan dalam Undang-undang Ormas itu sendiri. Dalam sebuah pergerakan kehidupan berbangsa dan bernegara tentu masyarakat sipil diberi kebebasan dalam hal hak -hak serta kewajiban untuk berserikat berkumpul dan mengeluarkan pendapat, tentu pula dalam Negara seperti Indonesia yang menganut system kenegaraan demokrasi. Demokrasi khususnya demokrasi liberal 'yang sehat' tentunya publik juga diperlukan sebagai publik yang terorganisir untuk demokrasi, tersosialisasikan dengan ragam norma serta nilainya dan berkomitmen dengan bukan 
untuk kepentingan sempit namun pada tujuan yang lebih luas. Komunitas sipil seperti ini dimungkinkan melalui suatu 'masyarakat sipil' yang dinamis (Diamond, 2003:278).

Sehingga dijaman reformasi ini lah maka dibentuk Undang-undang 39 tahun 1999 tentang Hak Asasi Manusia dalam hal menjalani hidup dengan merdeka dan Undang-undang Nomor 9 tahun 1998 tentang Kemerdekaan Menyampaikan Pendapat DiMuka Umum,dan dibuat pula Undang-undang nomor 17 tahun 2011 tentang Ormas yang mana sudah diperaharui oleh Perpu nomor 2 tahun 2017 yang saat ini sudah di sahkan menjadi Undang-undang Ormas. Kemerdekaan menyatakan pendapat ini adalah implementasi dari nilai-nilai hak asasi manusia. Seperti ditulis oleh James W. Nickel dalam bukunya yang berjudul Making Sense Of Human Rights menyatakan bahwa ketika hak asasi manusia diimplementasikan didalam hukum internasional, kita masih menyebutnya sebagai hak asasi manusia.

Politik hukum dan praktik Pemerintah membubarkan Organisasi Kemasyarakatan (Ormas) dapat dianalisis berdasarkan perkembangan rumusan norma dan alasan pembentukan norma dalam sistem hukum di Indonesia. Politik hukum merupakan perumusan hukum yang beresensikan pembuatan dan pembaharuan terhadap materi-materi hukum agar dapat disesuaikan dengan kebutuhan dan pelaksanaan ketentuan hukum yang sudah ada (Mahfud, 2009:26). Pasal 1 UU Ormas Lama memberikan definisi Ormas adalah organisasi yang dibentuk oleh anggota masyarakat Warga Negara Republik Indonesia secara sukarela atas dasar kesamaan kegiatan, profesi, fungsi, agama, dan kepercayaan terhadap Tuhan Yang Maha Esa, untuk berperan serta dalam pembangunan dalam rangka mencapai tujuan nasional dalam wadah Negara
Kesatuan Republik Indonesia yang berdasarkan Pancasila. UU Ormas Lama belum mengatur bentuk-bentuk dari Ormas yang ada, berarti seluruh organisasi yang ada di Indonesia dianggap terikat oleh peraturan ini, sehingga masih belum jelas ruang lingkup organisasi yang dimaksud dalam undangundang ini. Berdasarkan Pasal 26 PP No. 18 Tahun 1986, ditetapkan bahwa mekanisme pembubaran Ormas yaitu Pemerintah terlebih dahulu memberikan peringatan tertulis sebelum melakukan tindakan pembubaran. Apabila dalam jangka waktu 3 (tiga) bulan setelah menerima peringatan tertulis, Ormas belum memenuhi ketentuan maka Pemerintah dapat membubarkan organisasi kemasyarakatan yang bersangkutan. Namun sebelum melakukan tindakan pembubaran perlu pertimbangan, yaitu: a. Bagi Ormas yang mempunyai ruang lingkup Nasional, Pemerintah Pusatmeminta pertimbangan dan saran dalam segi hukum dari Mahkamah Agung; b. Bagi Omas yang mempunyai ruang lingkup Propinsi atau Kabupaten/Kotamadya, Gubemur atau Bupati/Walikotamadya meminta pertimbangan dan saran dari instansi yang berwenang di daerah serta petunjuk dari Menteri Dalam Negeri. Berikutnya, UndangUndang No. 17 Tahun 2013 tentang Organisasi Kemasyarakatan (UU Ormas) merupakan undang-undang yang membawa harapan era reformasi dengan lebih mengedepankan semangat demokrasi dan perlindungan hak asasi manusia. Peraturan ini diterbitkan oleh Presiden Susilo Bambang Yudhoyono sebagai respon memberikan kepastian hukum terhadap aturan terkait Ormas yang masih belum lengkap. Perlu diingat bahwa, Ormas secara kelembagaan dibentuk agar masyarakat dapat berperan aktif mengatasi persoalan bangsa dan mengaktualisasi diri serta berperan serta secara aktif dalam mewujudkan masyarakat Pancasila berdasarkan Undang-Undang Dasar 1945. 
PENUTUP

Kesimpulan

Dari penelitian tersebut dapat diambil Negara atau pemerintah dapat melindungi hak asasi manusia dari tindakan anarkis sepertihalnya persekusi yang pernah terjadi sebelumnya, dengan diberlakukannya penjatuhan sanksi administratif secara bertahap kepada organiasi kemasyarakatan yang melanggar ketentuan administratif dan saknsi pidana kepada setiap orang yang bernaung dalam organisasi kemasyarakatan sebagai bentuk pertanggungjawaban pidana yang melanggar ketentuan pidana. Sehingga diharapkan organisasi kemasyarakatan dapat secara tertib dalam hal pengelolaan kegiatan secara administratif terlebih dalam hal ini dititik beratkan pada aktifitas organisasi kemasyarakatan yang tidak boleh menjadi mesin partai politik dan dalam konteks hukum pidana yang diatur didalamnya bertujuan guna menekan potensi anarkis yang sering terjadi yakni main hakim sendiri dan persekusi yang baru-baru ini terjadi.

\section{Saran}

Meskipun dalam Undang-undang No 16 Tahun 2017 Tentang Organisasi Kemasyarakatan, telah mempersempit celah untuk menekan perbuatan melawan hukum pidana yang dilakukan setiap anggota ormas. Namn nampaknya khusus dalam konteks ini mesti diperjelas berkaitan dengan beban pertanggungjawaban subjek hukum pidana didalamnya sehingga tidak lagi dengan mudah ditafisrkan bahwa setiap Organisasi Kemasyarakatan yang melanggar ketentuan hukum pidana maka seluruh anggotanya harus mempertanggung jawabkan haltersebut, meskipun hal tersebut merupakan penafsiran subjektif dari seorang pakar hukum, namun tanpa ada penegasan berkaitan dengan hal tersebut, maka tujuan dari lahirnya Undang-undang No 16 Tahun 2017 Tentang Organisasi Kemasyarakatan yang menginginkan Organisasi Kemasyarakatan yang taat hukum tidak akan tercapai hal tersebut dikarenakan setiap orang dapat secara bebas menafsirkan ketentuan pidana tersebut.

\section{DAFTAR PUSTAKA}

A.V Dicey, Introduction to the Study of the Law of the Constitutin (terj), Bandung: Nusamedia, 2008.

Antonius Cahyadi dan E. Fernando M. Manullang, Pengantar ke Filsafat Hukum, Cet. I, Jakarta: Kencana Prenada Media Group, 2007.

Diamond, Larry. 2003. Developing Democracy: Toward Consolidation, Yogyakarta: IRE Press, 2003.

Franz Magnis Suseno, Kuasa dan Moral, Jakarta: Gramedia Pustaka Utama, 1988.

Jimly Asshiddiqie, Kemerdekaan Berserikat, Pembubaran Partai Politik dan Mahkamah Konstiusi, Jakarta: Konstitusi Press, 2006.

MD, Mahfud. Politik Hukum di Indonesia. Depok: PT Raja Grafindo Persada, 2009

Rukmana Aman Winata, Kemerdekaan berserikat dan berkumpul dalam pasal 28 UUD 1945, Bandung: Lembaga Penelitian UNPAD,200o.

Suharto, Edi. Membangun Masyarakat Memberdayakan Rakyat. Bandung: Refika

Aditama. 2005 
